\title{
KEBUTUHAN PROTEIN DALAM PAKAN UNTUK PERTUMBUHAN YUWANA IKAN KERAPU BATIK (Epinephelus polyphekadion)
} \begin{abstract}
ABSTRAK
Tujuan penelitian ini adalah untuk mengetahui pengaruh perbedaan kandungan protein dalam pakan buatan terhadap pertumbuhan yuwana kerapu batik ( $E$. polyphekadion). Ikan untuk penelitian ini mempunyai kisaran bobot awal $5,4 \pm 0,71 \mathrm{~g}$ dan kisaran panjang total $6,8 \pm 0,39 \mathrm{~cm}$ dipelihara dalam 15 bak polikarbonat dengan volume $30 \mathrm{~L}$ dan kepadatan 12 ekor ikan/bak. Bak dilengkapi sistem aerasi dan air mengalir dengan pergantian air $20 \mathrm{~L} / \mathrm{jam}$. Pakan penelitian berupa pelet kering dengan kandungan protein $36 \%, 42 \%, 48 \%, 54 \%$, dan $60 \%$. Pakan diberikan 2 kali sehari secara ad libitum dan ikan dipelihara selama 70 hari. Hasil penelitian menunjukkan bahwa bobot akhir, laju pertumbuhan spesifik, pertambahan bobot, dan efisiensi pakan dipengaruhi oleh kandungan protein pakan $(P<0,05)$, sedangkan konsumsi pakan, rasio efisiensi protein, dan komposisi akhir tubuh ikan tidak berbeda nyata antar perlakuan $(P>0,05)$. Nilai bobot kandungan protein $54 \%$ spesifik, pertambahan bobot, dan efisiensi pakan tertinggi dicapai pada metapi tidak berbeda nyata dengan kandungan $48 \%$ dan $60 \%$. Hasil ini menunjukkan bahwa yuwana ikan kerapu batik membutuhkan pakan dengan kandungan protein $48 \%$ untuk tumbuh dengan baik.
\end{abstract}

ABSTRACT: The dietary protein requirement on growth of marble grouper (Epinephelus polyphekadion) juveniles. By: Muhammad Marzuqi, Nyoman Adiasmara Giri,
and Ketut Suwirya

The purpose of this experiment was to know the effect of different level of dietany protein on growth of marble grouper (E. polyphekadion) juveniles. Fishes with body weight of $5.4 \pm 0.71 \mathrm{~g}$ and total length $6.8 \pm 0.39 \mathrm{~cm}$ were reared in 15 paces polycarbonate tank with density of 12 fishes/tank. The experimental diet was pellet repaired containing different level of protein i.e. $36 \%$, $42 \%, 48 \%, 54 \%$, and $60 \%$. The diet was given 2 times/day during 70 days. The result showed that the marble grouperein influenced on specific growth rate, body weight gain and feed efficiency of final body grouper $(P<0.05)$, but not influenced on feed consumption, protein efficiency ratio, and final body composition $(P>0.05)$. The growth rate, specific growth rate, body weight gain, and feed $60 \%$. These data on protein level $54 \%$, but not significantly different on protein level $48 \%$ and juveniles was $48 \%$

KEYWORDS: marble grouper, dietary protein, growth

\section{PENDAHULUAN}

Ikan kerapu termasuk ikan yang memiliki nilai ekonomis penting, karena memiliki harga yang cukup tinggi dan sangat potensial dikembangkan untuk budi daya. Satu di antara jenis kerapu yang memiliki harga yang cukup tinggi adalah kerapu batik (Epinephelus polyphekadion). Usaha budi daya ikan kerapu batik masih relatif baru dibandingkan jenis ikan kerapu lainnya seperti ikan kerapu tikus, kerapu macan, dan kerapu lumpur. Penelitian pada kerapu batik baru dilakukan pada tahun 1989 oleh Tawada, kemudian diikuti oleh James et al. $(1997,1998)$. Di Indonesia, penelitian dirintis oleh Slamet \& Tridjoko (1997) dan Marzuqi et al. (2001). Aspek-aspek yang diteliti sebatas aspek biologi, reproduksi, dan teknis pemeliharaan larva. Sedangkan kebutuhan nutrisi baru dilakukan terhadap induk (Giri et al., 1999a). James et al. (1997) mencatat sintasan larva kerapu batik mencapai $2,98 \%$ sampai umur 50 hari. Informasi hasil penelitian untuk sintasan pada ukuran yuwana sampai ukuran konsumsi belum ada. Yunus et al. (1999) dalam Marzuqi et al. (2001) melaporkan bahwa pada stadia larva sintasan ikan kerapu batik baru mencapai $0,63 \%$ sampai umur 20 hari pada skala laboratorium.

Kendala utama pengembangan budi daya ikan kerapu batik adalah terbatasnya persediaan benih dan belum tersedianya pakan yang sesuai. Pada ukuran yuwana ikan kerapu batik masih diberi ikan rucah sebagai pakan. Penggunaan pakan ikan rucah banyak kendala, karena ketersediaannya sangat tergantung

Peneliti pada Balai Besar Riset Perikanan Budidaya Laut, Gondol 
dengan musim dan sangat rentan terhadap kontaminasi bibit penyakit. Oleh karena itu, perlu dikembangkan pakan buatan yang mempunyai nilai nutrisi yang lengkap dan seimbang. Tetapi saat ini pengembangan pakan untuk ikan kerapu batik belum dapat dilakukan karena belum tersedianya data tentang kebutuhan nutrisi pakan.

Salah satu kebutuhan nutrisi yang penting untuk ikan adalah protein. Protein merupakan unsur pokok dari jaringan dan organ tubuh, sehingga suplai yang berkesinambungan diperlukan dalam pakan untuk pertumbuhan dan perbaikan jaringan. Kekurangan protein dalam pakan dapat menyebabkan terhambatnya pertumbuhan, diikuti oleh kehilangan bobot tubuh karena pemakaian protein dari jaringan tubuh untuk memelihara fungsi vital (Akiyama et al., 1991).

Kebutuhan protein untuk berbagai jenis ikan yang dibudidayakan di laut telah dilaporkan oleh beberapa peneliti. Teng et al. (1978) melaporkan bahwa yuwana Epinephelus salmoides membutuhkan protein sebesar $50 \%$, Epinephelus akaara sebesar $49,5 \%$ (Chen et al., 1995); Epinephelus malabaricus sebesar $47,8 \%$ (Chen \& Tsai, 1994); dan Epinephelus striatus lebih dari $55 \%$ (Ellis et al., 1996). Ikan kerapu sebagai ikan karnivora membutuhkan pakan dengan kadar protein yang relatif tinggi. Giri et al. (1999b) melaporkan bahwa kebutuhan protein untuk pertumbuhan berbagai kerapu relatif tinggi yaitu $47,8 \%-60 \%$ dan yuwana kerapu bebek ( $C$. altivelis) membutuhkan protein sebesar $54,2 \%$ (Giri et al., 1999b). Selain spesies ikan, adanya variasi ini sangat dipengaruhi oleh kondisi penelitian dan sumber protein yang digunakan.

Mengingat pentingnya peran protein dalam pakan untuk ikan kerapu, maka perlu dilakukan penelitian untuk menentukan kebutuhan protein dalam pakan bagi usaha pengembangan budi daya ikan kerapu batik.

\section{BAHAN DAN METODE}

Pakan uji yang digunakan berupa pelet kering ( $d r y$ pellet) dengan kadar protein berbeda yaitu $36 \%, 42 \%$, $48 \%, 54 \%$, dan $60 \%$. Bahan baku yang digunakan berupa kasein, tepung ikan, tepung cumi, dan tepung rebon sebagai sumber protein. Pakan dianalisis kandungan protein, lemak, serat, abu, dan energinya. Adapun komposisi pakan dan analisis proksimat disajikan pada Tabel 1. Penelitian ini dirancang menggunakan rancangan acak lengkap (RAL) dengan menggunakan 5 kandungan protein yang berbeda sebagai perlakuan dan tiap perlakuan diulang 3 kali.

Tabel 1. Komposisi pakan penelitian (\%)

Table 1. The composition of test diet (\%)

\begin{tabular}{|c|c|c|c|c|c|}
\hline \multirow{2}{*}{ Bahan (Ingredients) } & \multicolumn{5}{|c|}{ Protein pakan (Dietary protein) $(\%)$} \\
\hline & 36 & 42 & 48 & 54 & 60 \\
\hline Kasein (Casein) & 13.0 & 16.0 & 19.0 & 22.0 & 25.0 \\
\hline Tepung ikan (Fish meal) & 29.0 & 33.0 & 37.0 & 41.0 & 45.0 \\
\hline Tepung hati cumi (Squid liver meal) & 6.0 & 7.0 & 8.0 & 9.0 & 10.0 \\
\hline Tepung rebon (Tiny shrimp meal) & 4.5 & 4.9 & 5.4 & 5.8 & 6.2 \\
\hline Pati $(\alpha-s t a r c h)$ & 32.3 & 25.4 & 18.5 & 11.6 & 4.7 \\
\hline Minyak ikan (Fish oil) & 5.1 & 4.6 & 4.0 & 3.5 & 3.0 \\
\hline Mineral mix & 1.7 & 1.7 & 1.7 & 1.7 & 1.7 \\
\hline Vitamin mix ${ }^{2)}$ & 1.3 & 1.3 & 1.3 & 1.3 & 1.3 \\
\hline Astaxanthin & 0.1 & 0.1 & 0.1 & 0.1 & 0.1 \\
\hline Carboxy methyl cellulose & 3.0 & 3.0 & 3.0 & 3.0 & 3.0 \\
\hline Selulosa (Cellulose) & 4.0 & 3.0 & 2.0 & 1.0 & 0.0 \\
\hline Jumlah (Total) & 100 & 100 & 100 & 100 & 100 \\
\hline \multicolumn{6}{|l|}{$\begin{array}{l}\text { Komposisi proksimat }(\%) \text { : } \\
\text { Proximate composition (\%): }\end{array}$} \\
\hline - Protein (Protein) & 36.35 & 43.03 & 48.96 & 55.98 & 61.73 \\
\hline - Lemak (Lipid) & 9.11 & 9.53 & 9.05 & 9.00 & 9.24 \\
\hline - Abu (Ash) & 8.27 & 10.33 & 9.63 & 12.84 & 11.15 \\
\hline - BETN $(N \text {-free extract })^{3)}$ & 34.97 & 27.47 & 20.38 & 9.72 & 5.03 \\
\hline - Serat (Fibre) & 6.90 & 5.12 & 7.46 & 8.00 & 8.22 \\
\hline - Energi (kkal/g) (Energy) (kcal/g) ${ }^{3)}$ & 4.40 & 4.52 & 4.52 & 4.46 & 4.63 \\
\hline
\end{tabular}


*) Mineral (mg/100 g pakan) (Mineral mix) (mg/100 g diet): $\mathrm{KH}_{2} \mathrm{PO}_{4} 412 ; \mathrm{CaCO}_{3} 282 ; \mathrm{Ca}\left(\mathrm{H}_{2} \mathrm{PO}_{4}\right) 618 ; \mathrm{FeCl}_{3} .4 \mathrm{H}_{2} \mathrm{O}$ 166; $\mathrm{ZnSO}_{4}$ 9.99; $\mathrm{MnSO}_{4}$ 6.3; $\left.\mathrm{CuSO}_{4} 2 ; \mathrm{CoSO}_{4} .7 \mathrm{H}_{2} \mathrm{O}\right)$ 0.05; $\mathrm{KJ}_{4} 0.15$; Dekstrin 450; Selulosa 553.51

**) Vitamin mix (mg/100 g pakan) (Vitamin mix) (mg/100 g diet): Thiamin-HCl 5.0; riboflavin 5.0; 10.0; niacin 2.0; pyridoxin. $\mathrm{HCl}$ 4.0; biotin 0.6; folic acid 1.5; cyanocobalamin 0.01 ; inosin 5.0; Ca-pantothenate acid 5.0; menadion 4.0; vit A palmitat 15.0; chole.cald .5; cyanocobalamin 0.01; inositol 200; r-aminobenzoic

***) Total energi dihitung

Total energy based on kall lemak 9,45 kkal/g; dan karbohidrat 4,10

Total energy based on energy content of protein $5.65 \mathrm{kcal} / \mathrm{g}$; lipid $9.45 \mathrm{kcal} / \mathrm{g}$; dan carbohydrate 4.10)

Penelitian ini menggunakan yuwana ikan kerapu batik dengan kisaran bobot awal $5,4 \pm 0,71 \mathrm{~g}$ dan kisaran panjang total $6,8 \pm 0,39 \mathrm{~cm}$, yang berasal dari hasil pembenihan di Balai Besar Riset Perikanan Budidaya Laut, Gondol. Yuwana dipelihara dalam bak polikarbonat sebanyak 15 buah dengan volume $30 \mathrm{~L}$ yang dilengkapi dengan aerasi dan sistem air mengalir dengan pergantian air mencapai $20 \mathrm{~L} / \mathrm{jam}$.

Pemberian pakan dilakukan secara sedikit demi sedikit sebanyak 2 kali sehari sampai ikan tidak mau makan (ad libitum). Jumlah pakan yang diberikan per hari dihitung dengan melihat selisih bobot pakan sebelum dan sesudah pemberian pakan. Agar kondisi bak pemeliharaan tetap bersih maka kotoran dalam bak disipon setiap pagi hari sebelum pemberian pakan. Penelitian ini berlangsung selama 70 hari dan setiap minggu dilakukan pengamatan pertumbuhan (bobot dan panjang ikan). Penimbangan dilakukan terhadap semua ikan dalam setiap bak secara individu. Peubah biologis yang diamati meliputi laju pertumbuhan spesifik, pertambahan bobot, protein efisiensi rasio, efisiensi pakan, konsumsi pakan, sintasan, sedangkan peubah kualitas air yang diamati meliputi salinitas, $\mathrm{pH}$, suhu, $\mathrm{NO}_{2}, \mathrm{PO}_{4}, \mathrm{NO}_{3}$, dan $\mathrm{NH}_{3}$.

Pengaruh perlakuan diuji menggunakan analisis ragam bantu. Sebelum dilakukan uji sidik ragam, semua data yang diperoleh diuji dulu dengan uji homogenitas, uji additivitas, dan uji normalitas.
Setelah data-data tersebut bersifat homogen, additif, dan menyebar normal maka dilakukan uji F. Apabila hasil analisis memperlihatkan perbedaan yang nyata antar perlakuan maka dilanjutkan dengan Uji Tukey's untuk mengetahui perlakuan yang memberikan perbedaan serta penentuan perlakuan yang terbaik (Steel \& Torrie, 1995).

\section{HASIL DAN BAHASAN}

Hasil pengamatan terhadap laju pertumbuhan spesifik, pertambahan bobot, dan sintasan selama penelitian berlangsung terlihat pada Tabel 2 .

Dari data di atas menunjukkan bahwa kandungan protein berpengaruh nyata $(P<0,05)$ terhadap persentase pertambahan bobot dan laju pertumbuhan spesifik yuwana kerapu batik. Pertumbuhan tertinggi diperoleh pada kandungan protein $54 \%$, namun tidak berbeda nyata $(P>0,05)$ dengan kandungan protein $48 \%$ dan $60 \%$. Hasil ini menunjukkan bahwa kebutuhan protein bagi yuwana ikan kerapu batik hampir sama dengan jenis ikan kerapu lainnya. Pada ikan kerapu tikus (C. altivelis) membutuhkan kandungan protein $54,2 \%$ untuk menghasilkan pertumbuhan optimal (Giri et al., 1999b), sedangkan jenis lainnya seperti yuwana ikan kerapu E. salmoides mencapai 50\% (Teng et al., 1978), E. akara sebesar $49,5 \%$ (Chen et al., 1995), E. malabaricus sebesar $47,5 \%$ (Chen \& Tsai, 1994), dan E. striatus lebih dari

Tabel2. Laju pertumbuhan spesifik, pertambahan bobot, dan sintasan yuwana ikan kerapu batik ( $E$.
polyphekadion)

Table 2. Spesific growth rate, weight gain, and survival rate of marble grouper (E. polyphekadion)

\begin{tabular}{|c|c|c|c|c|c|}
\hline $\begin{array}{c}\text { Protein pakan } \\
(\%) \\
\text { Dietary protein } \\
(\%)\end{array}$ & $\begin{array}{c}\text { Bobot } \\
\text { awal }(g) \\
\text { Initial } \\
\text { weight }(g)\end{array}$ & $\begin{array}{l}\text { Bobot akhir }(\mathrm{g}) \\
\text { Final weight }(\mathrm{g})\end{array}$ & $\begin{array}{l}\text { Laju pertumbuhan } \\
\text { spesifik (\%hari) } \\
\text { Specific growth rate } \\
\text { (\%day) }\end{array}$ & $\begin{array}{l}\text { Pertambahan } \\
\text { bobot }(\%) \\
\text { Weight gain } \\
(\%)\end{array}$ & $\begin{array}{l}\text { Sintasan } \\
(\%) \\
\text { Survival } \\
\text { rate (\%) }\end{array}$ \\
\hline 36 & $4.7 \pm 0.71$ & $9.13 \pm 0.78^{a}$ & $0.75 \pm 0.12$ & $69.80 \pm 14.93^{a}$ & 97.22 \\
\hline 42 & $4.7 \pm 0.71$ & $9.63 \pm 0.50^{a b}$ & $0.83 \pm 0.07^{a b}$ & $77.39 \pm 10.97^{a}$ & 97.22 \\
\hline 48 & $4.7 \pm 0.71$ & $11.77 \pm 1.00^{c}$ & $1.11 \pm 0.12^{c}$ & $117.90 \pm 18.56^{b}$ & 91.67 \\
\hline 54 & $4.7 \pm 0.71$ & $11.90 \pm 0.26^{c}$ & $1.13 \pm 0.03^{c}$ & $120.37 \pm 4.90^{b}$ & 100.00 \\
\hline 60 & $4.7 \pm 0.71$ & $10.87 \pm 0.25^{b c}$ & $1.00 \pm 0.04^{b c}$ & $101.24 \pm 4.66$ ab & 97.22 \\
\hline
\end{tabular}

") Nilai pada kolom dengan huruf yang sama tidak berbeda nyata $(P>0,05)$

$V a l u e s$ in the column with the same letter are not significantly different $(P>0.05)$ 
$50 \%$ (Ellis et al., 1996). Tingginya kebutuhan protein pada ikan kerapu batik ini disebabkan oleh sifat ikan kerapu yang merupakan jenis ikan karnivora. Kandungan protein dalam pakan dapat berpengaruh terhadap tinggi rendahnya pertumbuhan ikan. Pemanfaatan protein untuk pertumbuhan sangat dipengaruhi oleh ukuran ikan, kualitas protein, kandungan energi pakan, keseimbangan gizi, dan tingkat pemberian pakan (Furnichi, 1988). Pada penelitian ini ikan yang digunakan masih dalam fase yuwana (bobot awal 5,4 g), sehingga protein yang diperlukan juga lebih besar daripada ikan ukuran konsumsi atau induk. Menurut NRC (1993), protein dalam proporsi pakan akan menurun ketika ikan semakin besar dan mendekati kematangan gonad. Kandungan protein $25 \%$ memberikan pertumbuhan terbaik pada Channel catfish (L. punctatus) ukuran $114-500 \mathrm{~g}$, sedangkan ukuran 14-120 g pertumbuhan terbaik dengan pakan berprotein 35\% (Page \& Andrew, 1973 dalam NRC, 1993). Pemberian pakan dengan kandungan protein $36 \%$ dan $42 \%$ dalam pemeliharaan yuwana kerapu batik menghasilkan persentase pertambahan bobot yang lebih lambat dibandingkan dengan kandungan 48\%-60\%. Hal ini mengindikasikan bahwa protein pakan di bawah kandungan $48 \%$ yang dikonsumsi ikan tidak mencukupi kebutuhan untuk metabolisme maupun untuk suplai asam amino dalam menyusun protein tubuhnya. Akiyama et al. (1991) menjelaskan bahwa protein diperlukan secara terus-menerus dalam jumlah yang cukup untuk pertumbuhan dan perbaikan jaringan. Kekurangan protein dalam pakan dapat menyebabkan terhambatnya pertumbuhan diikuti oleh kehilangan bobot yang disebabkan pemakaian protein tubuh untuk memelihara fungsi vital. Peningkatan kandungan protein pakan di atas tingkat optimum dapat menurunkan laju pertumbuhan dan efisiensi pakan sebagaimana dilaporkan oleh Vergara et al. (1996) untuk benih ikan Sparus aurata. Kebutuhan protein ikan Sparus aurata mencapai 55\% dengan laju pertumbuhan spesifik 2,4\% per hari. Peningkatan kandungan protein pakan menjadi $60 \%$ dan $65 \%$ menghasilkan laju pertumbuhan spesifik yang lebih rendah yaitu berturut-turut $2,23 \%$ dan $1,74 \%$ per hari. Fenomena ini dapat dijelaskan bahwa tidak tersedia cukup energi untuk deaminasi dan ekskresi kelebihan asam amino yang diabsorbsi dari pemecahan protein yang terlalu tinggi (Chen \& Tsai, 1994).

Hasil pengamatan pertambahan bobot (g) ikan setiap minggu disajikan dalam Gambar 1 .

Dari gambar di atas dapat dilihat bahwa pakan buatan dengan kandungan protein $36 \%$ perkembangan bobotnya tertinggal oleh pakan lainnya pada minggu ke-4, sedangkan pada minggu ke- 6 pakan dengan kandungan protein $42 \%$ mulai tertinggal dibandingkan dengan yuwana ikan kerapu batik yang diberi pakan dengan kandungan protein 48\%, 54\%, dan 60\%.

Efisiensi penggunaan pakan dan konsumsi pakan pada akhir percobaan disajikan pada Tabel 3. Efisiensi pakan menunjukkan peningkatan dengan meningkatnya kandungan protein $36 \%$ hingga $54 \%$.

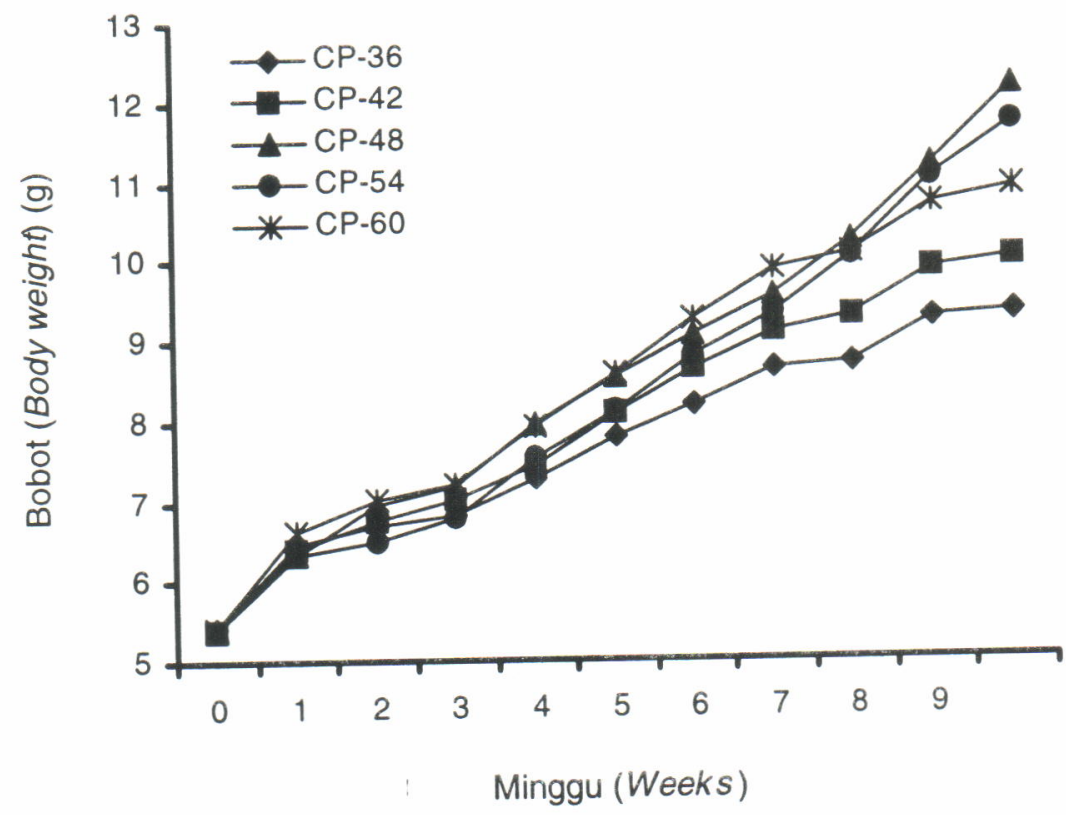

Gambar 1. Perkembangan bobot yuwana kerapu batik selama penelitian Figure 1. The body weight of marble grouper juveniles during experiment 
Efisiensi pakan tertinggi dicapai pada ikan yang diberi pakan dengan kandungan protein $54 \%$ dan berbeda nyata $(P<0,05)$ dibandingkan yang diberi pakan dengan kandungan protein $36 \%$ dan $42 \%$, namun tidak berbeda dengan pakan dengan kandungan protein $48 \%$ dan $60 \%$. Peningkatan kandungan protein ternyata dibarengi dengan tingginya efisiensi pakan. Efisiensi pakan tertinggi pada penelitian ini diperoleh sekitar 0,71. Efisiensi pakan pada ikan kerapu batik masih sangat rendah dibandingkan jenis kerapu lain. Pada ikan kerapu tikus dengan kadar protein yang sama menghasilkan efisiensi pakan sebesar 0,800,81 (Giri et al., 1999b), sedangkan pada yuwana ikan kerapu batik dengan ukuran $4,56-4,58 \mathrm{~g}$ yang diberi pakan dengan kandungan lemak $0 \%-15 \%$ sebesar $0,37-0,69$ (Suwirya et al., 2002). Hal ini diduga karena ikan kerapu batik termasuk ikan yang pertumbuhannya lambat. Penelitian yang dilakukan James et al. (1998) menunjukkan bahwa pada ikan kerapu batik untuk mencapai bobot 513-618 g membutuhkan waktu 12 bulan, sedangkan pada ikan kerapu macan (E. fuscoguttatus) hanya selama 7 bulan pemeliharaan dari fase larva. Hasil ini juga didukung oleh pendapat Giri et al. (1999b), di mana pada ikan kerapu tikus dengan bobot awal yang sama $(5,4-5,4 \mathrm{~g})$ pertumbuhan mencapai $274,2 \% \pm 12,6 \%$ pada kandungan protein $54 \%$ selama 50 hari pemeliharaan. Pemanfaatan pakan buatan pada ikan kerapu batik menunjukkan respon yang baik. Pakan yang dikonsumsi berkisar 8,18-9,69 g dari masing. masing perlakuan, masih berada dalam kisaran yang sempit dan tidak berbeda nyata antar perlakuan $(P>0,05)$. Ini menunjukkan bahwa kandungan protein dalam pakan tidak mempengaruhi konsumsi pakan. $\mathrm{Hal}$ ini diduga kandungan energi dalam pakan yang relatif sama. Selain itu suhu media pemeliharaan juga tidak berbeda yaitu sekitar $27^{\circ} \mathrm{C}-29^{\circ} \mathrm{C}$. Johnson et al. (2002) melaporkan bahwa kandungan energi pakan serta suhu media akan mempengaruhi konsumsi pakan, di mana kandungan energi pakan yang tinggi dapat mengurangi konsumsi pakan. Semakin tinggi suhu sampai batas tertentu, juga akan meningkatkan konsumsi pakan.

Dari data pada Tabel 3 juga terlihat bahwa nilai rasio efisiensi protein serta komposisi efisiensi protein dan lemak tubuh ikan pada akhir penelitian tidak berbeda nyata untuk setiap perlakuan, namun ada kecenderungan bahwa semakin besar kadar protein maka nilai rasio protein juga semakin besar dan mengalami penurunan setelah kadar $48 \%$. Ini diduga karena sumber protein yang digunakan sebagai bahan pakan memiliki komposisi asam amino yang lengkap serta daya cerna yang baik. Tepung ikan sebagai sumber protein utama mempunyai kandungan asam amino yang seimbang untuk memenuhi kebutuhan ikan (NRC, 1993). Dilaporkan oleh Akiyama et al. (1991) bahwa nilai daya cerna protein hewani lebih baik daripada protein nabati. Selain itu penggunaan kasein sebagai sumber protein murni dapat meningkatkan pemanfaatan protein dalam pakan, karena protein dari kasein juga memiliki nilai cerna yang tinggi.

Data kualitas air selama pemeliharaan ikan kerapu batik masih berada dalam batas normal untuk keperluan budi daya. Data kisaran kualitas air disajikan pada Tabel 4.

Selama masa pemeliharaan, kualitas air masin berada dalam kisaran aman bagi sintasan ikan. Ini disebabkan sistem pemeliharaan yang digunakan berupa sistem air mengalir sehinggga kestabilan parameter kimia air dapat terjaga. Kematian ikan penelitian selama pemeliharaan dipertimbangkan bukan karena pengaruh pakan.

Tabel 3. Konsumsi pakan dan efisiensi pakan yuwana kerapu batik

Table 3. Feed intake and feed efficiency ratio of marble grouper juveniles

\begin{tabular}{cccccc}
\hline $\begin{array}{c}\text { Protein } \\
\text { pakan(\%) } \\
\text { Dietary } \\
\text { protein (\%) }\end{array}$ & $\begin{array}{c}\text { Konsumsi } \\
\text { pakan } \\
\text { Feed intake }\end{array}$ & $\begin{array}{c}\text { Efisiensi } \\
\text { pakan } \\
\text { Feed } \\
\text { efficiency }\end{array}$ & $\begin{array}{c}\text { Rasio efisiensi } \\
\text { protein } \\
\text { Protein } \\
\text { efficiency ratio }\end{array}$ & $\begin{array}{c}\text { Kandungan protein } \\
\text { ikan (\%) } \\
\text { Protein of whole } \\
\text { body (\%) }\end{array}$ & $\begin{array}{c}\text { Kandungan lemak } \\
\text { ikan (\%) } \\
\text { Lipid of whole } \\
\text { body (\%) }\end{array}$ \\
\hline 36 & $9.69 \pm 0.49^{\mathrm{a}}$ & $0.38 \pm 0.07^{\mathrm{a}}$ & $1.07 \pm 0.24^{\mathrm{a}}$ & $55.39 \pm 2.95^{\mathrm{a}}$ & $16.90 \pm 2.49^{\mathrm{a}}$ \\
42 & $9.11 \pm 0.72^{\mathrm{a}} 0.46 \pm 0.03^{\mathrm{a}}$ & $1.13 \pm 0.18^{\mathrm{a}}$ & $58.31 \pm 4.57^{\mathrm{a}}$ & $14.70 \pm 1.64^{\mathrm{a}}$ \\
48 & $8.95 \pm 1.35^{\mathrm{a}}$ & $0.71 \pm 0.04^{\mathrm{b}}$ & $1.43 \pm 0.24^{\mathrm{a}}$ & $59.88 \pm 1.49^{\mathrm{a}}$ & $16.04 \pm 2.37^{\mathrm{a}}$ \\
54 & $8.94 \pm 0.81^{\mathrm{a}} 0.76 \pm 0.10^{\mathrm{b}}$ & $1.27 \pm 0.05^{\mathrm{a}}$ & $60.00 \pm 2.88^{\mathrm{a}}$ & $14.36 \pm 1.46^{\mathrm{a}}$ \\
60 & $8.18 \pm 0.53^{\mathrm{a}} 0.67 \pm 0.04^{\mathrm{b}}$ & $1.07 \pm 0.04^{\mathrm{a}}$ & $61.00 \pm 2.51^{\mathrm{a}}$ & $12.31 \pm 1.20^{\mathrm{a}}$ \\
\hline
\end{tabular}

Kandungan protein dan lemak awal ikan $58,42 \%$ dan $17,62 \%$

") Nilai pada kolom dengan huruf yang sama tidak berbeda nyata $(P>0,05)$

Values in the column with the same letter are not significantly different $(P>0.05)$ 
Tabel 4. Kualitas air selama penelitian

Table 4. Water quality during the experiment

\begin{tabular}{lccccc}
\hline \multirow{2}{*}{ Parameter } & \multicolumn{5}{c}{ Protein pakan (Dietary protein) (\%) } \\
\cline { 2 - 6 } & $\mathbf{3 6}$ & $\mathbf{4 2}$ & $\mathbf{4 8}$ & 54 & 60 \\
\hline $\mathrm{pH}$ & $8.10--8.31$ & $8.15--8.35$ & $8.03--8.31$ & $8.16--8.36$ & $8.17--8.32$ \\
Salinitas & $33--34$ & $33--34$ & $33--34$ & $33--34$ & $33--34$ \\
Salinity & & & & & \\
Suhu ( $\left.{ }^{\circ} \mathrm{C}\right)$ & $27--29$ & $27--29$ & $27--29$ & $27--29$ & $27--29$ \\
Temperature & & & & & \\
$\mathrm{NO}_{2}(\mathrm{mg} / \mathrm{L})$ & $0.05--0.08$ & $0.05--0.08$ & $0.06--0.08$ & $0.05--0.08$ & $0.05--0.07$ \\
$\mathrm{PO}_{4}(\mathrm{mg} / \mathrm{L})$ & $0.23--1.68$ & $0.31--1.25$ & $0.30--1.63$ & $0.30--1.65$ & $0.27--1.08$ \\
$\mathrm{NO}_{3}(\mathrm{mg} / \mathrm{L})$ & $0.31--0.38$ & $0.31--0.36$ & $0.31--0.36$ & $0.31--0.36$ & $0.25--0.37$ \\
$\mathrm{NH}_{3}(\mathrm{mg} / \mathrm{L})$ & $0.26--0.28$ & $0.26--0.28$ & $0.26--0.29$ & $0.26--0.30$ & $0.25--0.29$ \\
\hline
\end{tabular}

\section{KESIMPULAN}

1. Kandungan protein pakan berpengaruh terhadap laju pertumbuhan spesifik, pertambahan bobot, efisiensi pakan, dan tidak berpengaruh terhadap konsumsi pakan, rasio efisiensi protein dan kandungan protein, serta lemak ikan kerapu batik (E. polyphekadion).

2. Yuwana ikan kerapu batik (E. polyphekadion) membutuhkan pakan dengan kandungan protein $48 \%$ untuk tumbuh dengan baik.

\section{DAFTAR PUSTAKA}

Akiyama, D.M., W.G. Dominy, and A.L. Lawrence. 1991. Penaeid shrimp nutrition for the commercial feed industry. In. Proceedings of the Aquaculture Feed Processing and Nutrition Workshop. Thailand and Indonesia. September 19-25, 1991 (Akiyama, D.M. and Tan, R.K.H. Eds.). American Soybean Association Singapore, p. 80-98.

Chen, H.Y. and J.C. Tsai. 1994. Optimum dietary protein level for growth of juvenile grouper Epinephelus malabaricus fed semipurified diets. Aquaculture, 119: 265-271.

Chen, X., L. Lin, and H. Hong. 1995. Optimum content protein in artificial diet for Epinephelus akaara. J. Oceanography, 14: 407-412.

Ellis, S., G. Viala, and W.O.Watanabe. 1996. Growth and feed utilization of hatchery-reared juvenile nassau grouper fed four practical diets. Prog. Fish. Cult., 58: 167-172.

Furnichi, M. 1988. Dietary Requirement in Fish Nutrition in Mariculture (T. Watanabe ed.) Japan International Cooperation Agency, p. 9-79.

Giri, N.A., B. Slamet, dan Tridjoko. 1999a. Pematangan gonad dan pemijahan induk kerapu batik, Epinephelus microdon dengan perbaikan mutu pakan dalam Prosiding Seminar Nasional Penelitian dan Diseminasi Teknologi Budidaya Laut dan Pantai. Pusat Penelitian dan Pengembangan Perikanan, Jakarta 2 Desember 1999, p. 179-183.
Giri, N.A., K. Suwirya, dan M. Marzuqi. 1999b. Kebutuhan protein, lemak dan vitamin $C$ untuk yuwana ikan kerapu tikus (Cromileptes altivelis). J. Pen. Per. Indonesia, V (3): 38-46.

James, C.M., S.A. Al-Thobaiti, B.M. Rasem, and M.H. Carlos. 1997. Breeding and larvae rearing of the camouflage grouper Epinephelus polyphekadion (Bleeker) in the hypersaline water of the red sea coast of Saudi rabia. Aquaculture Research, 28: 671-681.

James, C.M., S.A. Al-Thobaiti, B.M. Rasem, and M.H. Carlos. 1998. Comparative growth of brown-marbled grouper Epinephelus fuscoguttatus (Forskal) and camouflage grouper Epinephelus polyphekadion (Bleeker) under hatchery and grow out culture condition. Asia Fisheries Science, 11: 133-147.

Johnson, E.G., W.O. Watanabe, and S.C. Ellis. 2002. Effect of dietary lipid levels and energy: Protein ratios on growth and feed utilization of juvenile nassau grouper fed isonitrogenous diets at two temperature. North American Journal of Aquaculture, 64: 47-54.

Marzuqi, M., N.A. Giri, K.M. Setiawati, dan K. Suwirya. 2001. Pemeliharaan larva kerapu batik (Epinephelus microdon) dengan awal pemberian pakan mikro pada umur yang berbeda dalam Prosiding Teknologi Budidaya Laut dan Pengembangan Sea Farming di Indonesia. Pusat Penelitian Eksplorasi Laut dan Perikanan, p. 190-196.

National Research Council. 1993. Nutrient Requirements of Fish. National Academy of Science. Washington, D.C., 114 pp.

Slamet, B. dan Tridjoko. 1997. Pengamatan pemijahan alami, perkembangan embrio, dan larva ikan kerapu batik Epinephelus microdon dalam bak terkontrol. J. Pen. Per. Indonesia, III(4): 40-50.

Steel, R.G.D. and J.H. Torrie. 1995. Prinsip dan Prosedur Statistika. Alih Bahasa: Bambang Sumantri. PT Gramedia Pustaka Utama, Jakarta, 748 pp.

Suwirya, K., N.A. Giri, dan M. Marzuqi. 1997. Kebutuhan lemak pakan untuk pertumbuhan yuwana ikan kerapu batik, Epinephelus microdon. Prosiding Lokakarya Nasional dan Pameran Pengembangan Agribisnis Kerapu II Jakarta, 8-9 Oktober 2002, p. 188-196. 
Tacon, A.G.J. 1987. The nutrition and of farmed fish and shrimp. A. training manual. The Essential Nutrients, FAO, Brazilia, Brazil.

Teng, S.K., T.E. Chua, and P.P.E. Lim. 1978. Preliminary observation on the dietary protein requirement of estuary grouper, Epinephelus salmoides. Maxwell
Cultured in Flouting net Cages. Aquaculture, 15: 257271.

Vergara, J.M., L. Ropbiana, M. Izquierdo, and M.D.L. Hiquera. 1996. Protein sparing effect of lipid in the diets for fingerling of gilthead sea bream. Fish. Sci., 62(4): $624-628$. 